\title{
PRODUKSI DAN KUALITAS JERAMI TANAMAN PROSO MILLET (Panicum miliaceum L.) DENGAN PEMBERIAN BERBAGAI ARAS UREA DAN PUPUK KANDANG SEBAGAI SUMBER PAKAN TERNAK
}

\author{
Akhmad Rizki' ${ }^{1}$ Eko Pangestu ${ }^{2}$ dan E. D. Purbajanti \\ 1) Mahasiswa Fakultas Peternakan Dan Pertanian Universitas Diponegoro \\ Kampus drh. Soejono Koesoemowardojo Tembalang Semarang 50275 \\ E-mail: ekopangestu57@gmail.com \\ ${ }^{2)}$ Fakultas Peternakan dan Pertanian, Universitas Diponegoro \\ Kampus drh. R. Soejono Kusumowardojo Tembalang, Semarang 50275
}

Diterima: 24 Januari 2016

Disetujui: 28 September 2016

\begin{abstract}
ABSTRAK
Penelitian ini bertujuan untuk mengkaji kadar bahan kering, serat kasar dan protein kasar jerami tanaman proso millet yang ditanam dengan perlakuan berbagai aras urea dan pupuk kandang. Rancangan penelitian menggunakan rancangan acak lengkap (RAL) pola faktorial $2 \times 3$ dengan 3 kali ulangan. Faktor pertama meliputi $\mathrm{M}_{0}$ (tanpa pupuk kandang) dan $\mathrm{M}_{1}$ (pupuk kandang) dengan taraf 5 ton/ha, sedangkan faktor kedua yaitu pemberian urea dengan level 50, 100, dan $150 \mathrm{~kg}$ N/ha. Data dianalisis berdasarkan sidik ragam dan dilanjutkan dengan uji wilayah ganda Duncan apabila ada perbedaan nyata. Hasil penelitian menunjukkan bahwa tidak ada interaksi antara pupuk kandang dengan urea. Pupuk kandang tidak berpengaruh pada kandungan bahan kering,serat kasar dan protein kasar. Perlakuan urea tidak berpengaruh pada produksi dan kandungan bahan kering tetapi berpengaruh pada kandungan serat kasar dan protein kasar. Kandungan serat kasar dan protein kasar dari pemupukan $\mathrm{N}_{1}, \mathrm{~N}_{2}$ dan $\mathrm{N}_{3}$ masing- masing sebesar 36,$93 ; 38,74 ; 43,62 \%$ dan 4,$28 ; 3,72 ; 6,03 \%$. Simpulan penelitian ini bahwa pemupukan $\mathrm{N}_{3}$ menghasilkan nutrien jerami proso millet yang terbaik.
\end{abstract}

Kata kunci: Millet, serat kasar, protein kasar, pemupukan

\section{PRODUCTION AND QUALITY OF PROSO MILLET (PANICUM MILIACEUM L.) WITH UREA AND MANURE AS ANIMAL FEED SOURCE}

\begin{abstract}
This study aims to the dry matter, crude fiber and crude protein of millet straw were planted with many level urea's and manure. Research using completely randomized design with a $2 \times 3$ factorial pattern 3 replications. The first factor is the level of manure consisting of $M_{0}$ (without manure) and $M_{1}$ (with manure) on degrees 5 ton/ha. The second factor is the level of urea which consists of $N_{1}(50 \mathrm{~kg} \mathrm{~N} / \mathrm{ha}), N_{2}(100 \mathrm{~kg} \mathrm{~N} / \mathrm{ha})$ and $N_{3}(150 \mathrm{~kg} \mathrm{~N} / \mathrm{ha})$. Data analysis of variance (ANOVA) and to know the difference between treatments continued with Duncan Multiple Range Test (DMRT). The results showed that interaction between manure and urea is not significant. Manure had not significant on the dry matter of production and contains while urea treatment had significant effect $(p<0,01)$ on the crude fiber and crude protein contains. The contain among of crude fiber and crude
\end{abstract}


protein from $N_{1}, N_{2}, N_{3}$ treatments are 36,$93 ; 38,74 ; 43,62 \%$ and 4,28; 3,72; 6,03\%. The conclusion of this research is that $N_{3}$ treatment give the best of nutrition value of straw proso millet.

Keywords: Millet, crude fiber, crude protein, fertilization

\section{PENDAHULUAN}

Proso millet (Panicum miliaceum L.) adalah jenis tanaman penghasil biji-bijian, merupakan jenis rumput yang dapat tumbuh subur pada musim panas dan mempunyai umur panen sekitar 60-90 hari sejak penanaman.. Proso millet oleh masyarakat dimanfaatkan bijinya sebagai pakan burung setelah itu, jeraminya belum banyak yang memanfaatkan sebagai pakan ternak ruminansia. Petani berasumsi bahwa jerami tanaman ini tidak bisa dimanfaatkan sebagai sumber pakan ternak. Padahal jika diteliliti lebih lanjut, tidak menutup kemungkinan jerami tanaman ini bisa sebagai sumber pakan ternak dan tentunya dengan perlakuan pemupukan yang baik

Pemupukan pada dasarnya bertujuan untuk memperbaiki tingkat kesuburan tanah agar tanaman mendapatkan nutrien yang cukup untuk meningkatkan kualitas dan kuantitas pertumbuhan tanaman. Pemupukan dapat menggunakan pupuk buatan seperti urea dan pupuk alami seperti pupuk kandang. Pupuk nitrogen yang secara umum digunakan untuk pemupukan yaitu urea yang mengandung $\mathrm{N}$ sekitar $45-46 \%$, sifatnya mudah menarik uap air (higroskopis) dan mudah terserap oleh tanaman (Lingga, 1986). Nitrogen bagi tanaman berfungsi untuk mempercepat pertumbuhan tanaman, menyehatkan pertumbuhan daun, meningkatkan kadar protein tanaman, meningkatkan kualitas tanaman serta meningkatkan perkembangan mikroorganisme dalam tanah. Pupuk kandang merupakan pupuk organik yang dapat menambah tersedianya unsur hara bagi tanaman yang dapat diserap dari dalam tanah. Kualitas pupuk kandang dipengaruhi oleh jenis ternak, kualitas pakan dan cara penampungan pupuk kandang. Pupuk kandang mempunyai pengaruh baik terhadap sifat fisik dan kimiawi tanah serta mendorong perkembangan jasad renik (Sutedjo, 1999). Pemberian beberapa pukan sapi, kambing dan ayam dengan takaran 5 ton/ha pada tanah latosol dapat meningkatkan kadar C-organik tanah (Adimihardja et al., 2000).

Analisis untuk memperoleh bahan kering dilakukan dengan cara mengeringkan dalam oven dengan suhu $105^{\circ} \mathrm{C}$ selama $4-5$ jam hingga mencapai berat konstan. Serat kasar didalam tanaman terdiri dari selulosa, hemiselulosa, dan liginin dimana selolusa merupakan material yang jumlahnya banyak sebagai penyusun dinding sel pada semua tanaman, ikatan molekulnya tidak dapat dicerna oleh pencernaan manusia kecuali pada hewan ternak ruminansia karena pada rumennya memiliki mikrobia yang dapat mencerna ikatan molekul pada selulosa (Tillman et al., 1991). Protein kasar atau crude protein merupakan nilai hasil bagi dari total nitrogen amonia dengan faktor $16 \%$ (16/100) atau merupakan hasil kali dari total nitrogen dengan faktor 6,25 (100/16), faktor $16 \%$ berasal dari asumsi bahwa protein mengandung nitrogen $16 \%$, nitrogen yang terdapat di dalam pakan tidak hanya berasal dari protein saja tetapi ada juga nitrogen yang berasal dari senyawa bukan protein atau nitrogen nonprotein (non-protein nitrogen /NPN) (Kamal, 1998). Kandungan nutrisi jerami proso millet (dalam bahan kering) protein kasar 
$4,8 \%$, serat kasar 35,5\% dan protein kasar protein kasar 6\% (Sampath, 1986; Zwinger and Schaubert, 2003).

Penelitian bertujuan untuk mengetahui produksi dan kualitas jerami millet ditinjau dari bahan kering, serat kasar dan protein kasar akibat pemberian berbagai aras urea dan pupuk kandang. Hasil yang diharapkan pada penelitian bahwa jerami tanaman proso millet dapat dijadikan salah satu alternatif sumber pakan ternak ruminansia.

\section{MATERI DAN METODE}

\section{Waktu dan Lokasi Penelitian}

Penelitian dilaksanakan pada bulan September sampai Desember 2014. Penanaman proso millet dilaksanakan di green house dan penelitian secara laboratoris dilakukan di laboratorium Ilmu Nutrisi Pakan dan Laboratorium Ekologi dan Produksi Tanaman, Fakultas Peternakan dan Pertanian, Universitas Diponegoro, Semarang.

\section{Materi Penelitian}

Materi yang akan digunakan dalam penelitian ini adalah pupuk urea, pupuk kandang, air, tanah Tembalang jenis latosol, dan biji proso millet yang diperoleh dari
Balai Tanaman Serealia Soropadan di Soropadan, Temanggung, Jawa Tengah. Peralatan yang digunakan adalah pot berdiameter $25 \mathrm{~cm}$ sebanyak 18 pot, gunting, selang untuk penyiraman dan label nama. Penelitian ini menggunakan materi tanaman proso millet yang diambil jeraminya dan diberi perlakuan kombinasi antara pupuk urea dengan pupuk kandang.

\section{Metode Penelitian}

Penelitian ini menggunakan rancangan percobaan Rancangan Acak Lengkap pola Faktorial 2x3 dengan 3 ulangan. Faktor pertama adalah pupuk kandang $\mathrm{M}_{0}$ (tanpa pupuk kandang) dan $\mathrm{M}_{1}$ (dengan pupuk kandang 5 ton/ha). Faktor kedua adalah level urea masingmasing $\mathrm{N}_{1}(50 \mathrm{~kg} \mathrm{~N} / \mathrm{ha}), \mathrm{N}_{2}$ (100 kg N/ha) dan $\mathrm{N}_{3}$ (150 kg N/ha).

$$
\text { Tanah yang telah disiapkan }
$$
dimasukkan kedalam 18 buah pot masingmasing $10 \mathrm{~kg} /$ pot kemudian $\mathrm{M}_{1}$ diberi pupuk kandang. Setelah 2 minggu biji ditanam sedalam $4 \mathrm{~cm}$ bersamaan dengan urea. Penyiraman dilakukan satu kali pada pagi hari.

\section{HASIL DAN PEMBAHASAN}

\section{Produksi dan Kandungan Bahan Kering}

Tabel 1 menampilkan rerata hasil analisis laboraturium produksi dan kandugan bahan kering jerami proso millet.

\begin{tabular}{|c|c|c|c|c|}
\hline & $\mathrm{N}_{1}$ & $\mathrm{~N}_{2}$ & $\mathrm{~N}_{3}$ & Rerata (M) \\
\hline Produksi & & ----- & -----. & \\
\hline $\mathrm{M}_{0}$ & 4,65 & 5,49 & 5,42 & 5,19 \\
\hline $\mathrm{M}_{1}$ & 4,88 & 4,60 & 4,69 & 4,72 \\
\hline Rerata $(\mathrm{N})$ & 4,77 & 5,05 & 5,06 & \\
\hline Kandungan & & & & \\
\hline $\mathrm{M}_{0}$ & 4,11 & 4,04 & 4,38 & 4,18 \\
\hline $\mathrm{M}_{1}$ & 4,31 & 4,14 & 4,24 & 4,23 \\
\hline Rerata $(\mathrm{N})$ & 4,21 & 4,09 & 4,31 & \\
\hline
\end{tabular}


Hasil sidik ragam menunjukkan bahwa tidak ada pengaruh interaksi terhadap kandungan bahan kering jerami proso millet. Berdasarkan Tabel 1 rerata bahan kering menunjukkan angka yang tidak jauh berbeda Hasil tersebut disebabkan karena sifat kedua jenis pupuk tersebut yang berbeda. Pupuk kandang merupakan pupuk organik sedangkan pupuk urea merupakan pupuk buatan atau pupuk anorganik, sehingga proses dekomposisinya juga berbeda (Lingga dan Marsono, 2008). Perbedaan kedua jenis pupuk tersebut mengakibatkan tanaman kesulitan untuk menyerap unsur secara bersamaan karena pupuk kandang memerlukan proses yang lebih lama dalam mendekomposisikan kandungan nutrisi dalam pupuk kandang meskipun dalam penelitian ini pupuk kandang sudah diberikan lebih awal dari pada pupuk urea. Pupuk kandang terutama kotoran sapi mempunyai kadar $\mathrm{C} / \mathrm{N}$ yang tinggi yaitu diatas 40, sehingga tidak bisa langsung diberikan kedalam tanah (Hartatik dan Widowati, 2006).

Berdasarkan hasil sidik ragam menunjukkan bahwa pemberian pupuk kandang dan urea tidak berbeda nyata $(\mathrm{P}>0,05)$, hal tersebut dikarenakan penyerapan hara nitrogen oleh tanaman kurang optimal. Kekurangan nitrogen akan menghambat produktiftas tanaman Sirait et al. (2005). Kandunga bahan kering juga dipengaruhi oleh penyinaran matahari, iklim dan juga umur tanaman (Haryati, 2012). Reksohadiprodjo (1994) menambahkan bahwa faktor yang mempengaruhi kandungan bahan kering pada tanaman yaitu: jenis tanaman, fase pertumbuhan, saat pemotongan, air tanah serta kesuburan tanah .

Proses fotosintesis juga mempengaruhi kandungan bahan kering suatu tanaman. Penelitian Triyanto et al. (2013) melaporkan bahwa fotosintesis tanaman dipengaruhi oleh cahaya, $\mathrm{CO} 2$, air, suhu, unsur hara, luas daun dan kadar klorofil, sehingga meningkatnya proses fotosintesis yang mengakibatkan pertumbuhan dan perkembangan rumput gajah semakin meningkat dan akan meningkatkan produksi tanaman, pada gilirannya akan meningkatkan pertambahan berat basah dan berat kering

\section{Kandungan Serat Kasar}

Tabel 2 menampilkan rerata kandungan serat kasar jerami proso millet.

\begin{tabular}{ccccc}
\hline \hline & $\mathbf{N}_{\mathbf{1}}$ & $\mathbf{N}_{\mathbf{2}}$ & $\mathbf{N}_{\mathbf{3}}$ & Rerata \\
\hline $\mathbf{M}_{0}$ & $-------------(\% B K)-------------$ & & \\
$\mathbf{M}_{1}$ & 36,60 & 38,07 & 46,21 & $40,29^{\mathrm{a}}$ \\
Rerata & 37,25 & 39,40 & 41,02 & $39,22^{\mathrm{a}}$ \\
\hline
\end{tabular}

${ }^{\mathrm{a}, \mathrm{b}}$ Superskrip dengan huruf yang berbeda pada baris dan kolom yang sama menunjukkan adanya perbedaan nyata $(\mathrm{P}<0,05)$

Hasil analisis sidik ragam level pupuk kandang juga tidak menunjukkan bahwa tidak ada pengaruh berpengaruh nyata $(\mathrm{P}>0,05)$ terhadap interaksi antara pemberian level pupuk kandungan serat kasar jerami proso millet. kandang dengan urea terhadap kandungan Hasil tersebut dikarenakan perbedan kedua serat kasar jerami proso millet. pemberian jenis pupuk dimana pupuk kandang 
merupakan pupuk organik sedangkan pupuk urea merupakan pupuk anorganik atau buatan sehingga kedua pupuk tersebut mempunyai sifat dan karakteristik yang berbeda (Lingga dan Marsono, 2008). Steel dan Torrie (1993) menambahkan apabila kedua faktor berpengaruh tidak nyata dapat disimpulkan bahwa kedua faktor-faktor tersebut bertindak bebas antara satu dengan yang lainnya.

Berdasarkan sidik ragam menunjukkan bahwa faktor urea memberikan pengaruh yang berbeda sangat nyata $(\mathrm{P}<0,01)$ terhadap kandungan serat kasar jerami proso millet. Hasil uji wilayah ganda Duncan menunjukkan bahwa faktor $\mathrm{N}_{3}$ memberikan hasil tertinggi terhadap kandungan serat kasar jerami proso millet. hasil tersebut tidak sejalan dengan pernyataan Susilawati et al. (2012) yang menyatakan bahwa tanaman yang kekurangan nitrogen maka kandungan serat kasarnya semakin tinggi.

Meskipun $\mathrm{N}_{3}$ (Tabel 2) memberikan hasil kandungan serat kasar paling tinggi, hal ini tidak mempengaruhi daya cerna terhadap ternak ruminansia. Zwinger and Schaubert (2013) melaporkan kandungan nutrisi jerami proso millet adalah sebagai berikut protein kasar 6\%, ADF 41,1\%, NDF $67,4 \%$, Ca $0,60 \%$, fospor $0,18 \%$, magnesium $0,32 \%$, kalium $2,00 \%$, sulfur $0,16 \%$ dan energi dapat dicerna $56,9 \%$. Data tersebut menunjukkan bahwa jerami proso millet potensial untuk dijadikan alternatif sumber pakan ternak terutama ternak ruminansia.

\section{Kandungan Protein Kasar}

Tabel 3 menampilkan rerata kandungan protein kasar jerami proso millet

\begin{tabular}{|c|c|c|c|c|}
\hline & $\mathrm{N}_{1}$ & $\mathbf{N}_{2}$ & $\mathbf{N}_{3}$ & Rerata \\
\hline & ------------- & ----- & & \\
\hline $\mathrm{M}_{0}$ & 4,49 & 3,97 & 6,04 & $4,83^{\mathrm{a}}$ \\
\hline $\mathrm{M}_{1}$ & 4,06 & 3,47 & 6,02 & $4,52^{\mathrm{a}}$ \\
\hline Rerata & $4,28^{\mathrm{b}}$ & $3,72^{\mathrm{b}}$ & $6,03^{\mathrm{a}}$ & \\
\hline
\end{tabular}

${ }^{\mathrm{a}, \mathrm{b}}$ Superskrip dengan huruf yang berbeda pada baris dan kolom yang sama menunjukkan adanya perbedaan nyata $(\mathrm{P}<0,05)$

Berdasarkan sidik ragam menunjukkan bahwa tidak ada pengaruh interaksi $(\mathrm{P}>0,05)$ antara pupuk kandang dengan urea. Faktor pupuk kandang juga tidak berpengaruh terhadap kandungan protein kasar jerami proso millet. Hasil tersebut dikarenakan kedua jenis pupuk bekerja secara bebas sehingga tidak saling memberikan pengaruh (Steel dan Torrie, 1993). Kandungan protein kasar juga dipengaruhi oleh unsur nitrogen yang diserap oleh tanaman dan jumlahnya juga tergantung substrat pelarutnya (Purbajanti et al., 2011), diduga beberapa unsur tercuci saat penyiraman. Kandungan nitrogen didalam pupuk kandang juga minim dan sulit terdekomposisi, hal ini juga akan mempengaruhi kandungan protein kasar tanaman (Hartatik dan Widowati, 2006).

Hasil sidik ragam menunjukkan bahwa urea berpengaruh sangat nyata $(\mathrm{P}<0,05)$ terhadap kandungan protein kasar jerami proso millet. Hasil pada Tabel 3 kolom urea menunjukkan hasil kandungan jerami proso millet yang semakin meningkat. Dapat disimpulkan bahwa kandungan protein kasar dipengaruhi oleh level pemberian urea dimana kandungan nitrogen dalam urea tinggi yaitu mencapai 43 hingga 45\% (Permata, 2012). Hidayat 
dan suwarno (2012) menambahkan bahwa kelebihan urea dibanding kompos adalah dapat menyediakan unsur hara pada saat yang tepat dibutuhkan tanaman. Urea secara cepat dapat menyediakan hara nitrogen. Hara nitrogen sebagai komponen protein dan klorofil dibutuhkan tanaman dalam jumlah banyak, dan kelebihan unsur $\mathrm{N}$ tidak menimbulkan keracunan bagi tanaman, lain dengan hara mikro seperti $\mathrm{Al}$ dan $\mathrm{Fe}$, apabila kelebihan hara mikro tersebut dapat meracuni tanaman. Jika kelebihan, nitrogen oleh tanaman akan diakumulasi di jaringan daun, sehingga kandungan protein daun juga meningkat.

\section{SIMPULAN DAN SARAN}

\section{Simpulan}

Berdasarkan hasil penelitian yang dilaksanakan dapat disimpulkan bahwa pemupukan $\mathrm{N}_{3}$ menghasilkan nutrien jerami millet yang terbaik.

\section{Saran}

Disarankan penggunaan pemupukan $\mathrm{N}_{3} \quad$ (150 kg N/ha) untuk menghasilkan nutrien jerami millet yang terbaik.

\section{DAFTAR PUSTAKA}

Adimihardja, A., I. Juarsah, dan U. Kurnia. 2000. Pengaruh penggunaan berbagai jenis dan takaran pupuk kandang terhadap produktivitas tanah Ultisols terdegredasi di Desa Batin, Jambi, hlm. 303-309. Prosiding. Seminar Nasional Sumber Daya Tanah, Iklim, dan Pupuk. Buku II. Lido-Bogor, 6-8 Des. 1999. Pusat Penelitian Tanah dan Agroklimat, Bogor.
Anggorodi, R.1994. Ilmu Makanan Ternak Umum. Gramedia Pustaka Utama. Jakarta.

Hartatik, W dan L. R. Widowati. 2006. Pupuk Kandang. balittanah.litbang.pertanian.go.id. Diakses pada 07 Januari 2016.

Haryanti, S dan T. Meirina. 2009. Optimalisasi Pembukaan Porus Stomata Daun Kedelai (Glycine max (L) merril) pada Pagi Hari dan Sore. Bioma 11 (1): 18-23.

Hidayat, N dan Suwarno. 2012. Studi produksi dan kualitas rumput gajah (Penissetum purperium) varietas Thailand yang dipupuk dengan kombinasi organik-urea. Jurnal Pastura. 2 (1): 12 - 16.

Kamal, M. 1998. Nutrisi Ternak I. Rangkuman. Lab. Makanan Ternak, jurusan Nutrisi dan Makanan Ternak, Fakultas Peternakan, UGM. Yogyakarta.

Lingga, P. 1986. Petunjuk Penggunaan Pupuk. Cetakan I. PT. Penebar Swadaya, Jakarta.

Lingga, P., Marsono. 2008. Petunjuk Penggunaan Pupuk. Cetakan 26. PT. Penebar Swadaya, Jakarta.

Purbajanti, E. D., Anwar S. 2011. Kandungan protein dan serat kasar rumput benggala (Panicum maximum) dan rumput gajah (Pennisetum purpureum ) pada cekaman stres kering. Anim. Prod. 11 (2) 109-115.

Sampath, S, R,. 1986. Scope for using small millet as forage in India. In : A. Seetharam, K.W. Riley, G. Harinarayana (Ed.). Proceeding of the First Small Millet Workshop. 
Banglore, India 29 Oktober- 2 November 1986 . p. 341-345.

Sirait, J., N. D. Purwantari dan K. Simanihuruk. 2005. Produksi dan serapan nitrogen rumput pada naungan dan pemupukan yang berbeda. JITV 10 (3): 175-181.

Steel, Robert G. D. and James H. Torrie, 1993. Principle and Product Of Statistic. Prinsip Dan Produk Statistik. Terjemahan Bambang Sumantri. Gramedia Pustaka Utama, Jakarta

Susilawati, Iin, K. M. Herryawan, K. Lizah 2012. Hasil dan kandungan komponen serat kasar hijauan rumput benggala dengan pemberian molybdenum dan jenis legume pada pertanaman campuran rumput dan legum. Jurnal Pastura 2 (2): 74-78.

Sutedjo, M. M. 1999. Pupuk dan Cara Pemupukan. Cetakan ke-6. Rineka Cipta, Jakarta.

Tillman. A.D., H. Hartadi., S. Reksohadiprodjo., S. Prawirokusumo dan S Lebdosoekojo. 1991. Ilmu Makanan Ternak Dasar. Gadjah Mada Universitty Press. Fakultas Peternakan, UGM. Yogyakarta.

Triyanto, A., Nur Hidayat, Pudjiarti. 2013. Pengaruh level pemberian pupuk organik granul terhadap produksi bahan kering, jumlah anakan dan tinggi tanaman pada rumput gajah defoliasi ketiga. Jurnal Ilmiah Peternakan. 1(1): 374-380.

Zwinger, S., Schaubert, S. 2013. Proso Millet for Grain and Forage. NDSU Agriculture :https://www.ag.ndsu.edu/varietytria ls/carrington-rec/2013-trialresults/2013-trial-results-prosomillet-carrington. Diakses pada 12 November 2015. 